\title{
From traces to carpets: unravelling labour practices in the mines of Sierra Leone
}

Book or Report Section

Accepted Version

D'Angelo, L. (2018) From traces to carpets: unravelling labour practices in the mines of Sierra Leone. In: De Vito, C. and Gerritsen, A. (eds.) Micro-spatial histories of global labour. Palgrave-Macmilan, Cham, Switzerland, pp. 313-342. ISBN 9783319584898 doi: https://doi.org/10.1007/978-3-319-584904_12 Available at http://centaur.reading.ac.uk/84319/

It is advisable to refer to the publisher's version if you intend to cite from the work. See Guidance on citing.

To link to this article DOI: http://dx.doi.org/10.1007/978-3-319-58490-4_12

Publisher: Palgrave-Macmilan

All outputs in CentAUR are protected by Intellectual Property Rights law, including copyright law. Copyright and IPR is retained by the creators or other copyright holders. Terms and conditions for use of this material are defined in the End User Agreement. 


\section{www.reading.ac.uk/centaur}

\section{CentAUR}

Central Archive at the University of Reading

Reading's research outputs online 


\title{
From traces to carpets
}

\section{Unravelling labour practices in the mines of Sierra Leone}

\author{
Lorenzo D'Angelo
}

[In: Christian G. De Vito and Anne Gerritsen (eds.), 2018.

Micro-Spatial Histories of Global Labour, London, Palgrave Macmillan, pp. 313-342.]

\section{Introduction $^{1}$}

The awareness of the complexity and contradictions of the contemporary world labour organisation-at once local and global; fragmented and heterogeneous, but coordinated and integrated at multiple levels and scales-urges the elaboration of increasingly sophisticated methodologies and theoretical models capable of making sense of the multitude of spatial and temporal connections between events, people, places, and commodities. One of the difficulties for anthropologists and historians interested in grasping this complexity lies in finding ways to think and write about connections that embrace moving between micro and macro, and zooming in and out, in order to examine situations at multiple scales. ${ }^{2}$

For those scholars who define and know from the very beginning their categories and objects of investigation-for example, who are the workers or what is labour-it is relatively simple to understand and identify the boundaries of their field of analysis, and the ways to trace the historical and geographical links that exist between them. If the goal is, for example, to reconstruct the origins of a working practice, it might be sufficient to search in different places and times for that same practice and make the necessary explanatory or causative 
connections and comparisons. However, if the definitions of objects and categories of analysis are part of the investigation itself, and if these definitions are primarily related to what social actors actually $d o$, and not to what they are or they should be, then things become considerably more complicated. $^{3}$

In this paper the challenge is to think about labour and its specific practices not as predefined objects, eternal and strictly governed by the logic of global capital, but as the results of contingent encounters between countless numbers of events, people, and other working and non-working practices. Thinking about labour in this way means recognizing the fact that things are the way they are, but that the potential exist for them to be otherwise. Hence, the causes and effects of the capitalist mode of production do not arise by chance, at the same time they are not the inevitable results of an alleged universal history.

This paper explores an approach that oscillates between the 'fine-grained analysis'4 of micro-history and transnational labour history by examining a set of practices and working agreements among a specific group of workers-diamond miners operating in Sierra Leone. Many people of different backgrounds and a variety of experiences have worked in the alluvial diamond mines of Sierra Leone. Since the discovery of diamantiferous deposits in 1930 and the colonial concession to extract this mineral at the artisanal level in late 1950s, miners have had to deal with environmental risks, political instability, epidemics, and above all the random distribution of gems in the soil. In other words, alluvial diamond mining has always been a very risky and uncertain activity. ${ }^{5}$ Consequently, the division of potential profits is a crucial issue for these workers. As I came to realise during my fieldwork in Sierra Leone conducted intermittently between 2007 and 2011, the variety and complexity of mining practices and agreements is astonishing. Taken together, these agreements are practical solutions to contingent or contextual problems; they are heterogeneous but, to an extent, consistent: an assemblage of practices that embody the experiences of long-time miners. The 
key issue is to understand of how this set of situated working practices has taken shape historically.

One way to answer to this question is to trace the origins of this assemblage. Following the traces to the origins is a common strategy that seems to unite historical approaches as diverse as the microhistory of Carlo Ginzburg and the Global Labour History (GLH) of Marcel van der Linden. However, these scholars invoke 'following the traces' in different ways. For van der Linden, following the traces is a way of expressing the position that GLH should deal with connections between various contexts at different scales. In fact, van der Linden's recurring use of the phrase in his essays is more an exhortation than representative of the systematic employment of a methodology. As I will show in this paper, his study of the origins of modern labour management reveals the limits of this proposal based on the problematic concept of origin.

For Ginzburg the metaphor of the trace is central to the understanding of the evidential paradigm, that is, the epistemological model that emerged in the social sciences at the end of the nineteenth century. ${ }^{6}$ On closer examination this model also reveals some weaknesses and inconsistencies that Ginzburg does not fully resolve even when he relies on the concept of 'family resemblances' that he borrows from Wittgenstein.

I begin by highlighting the limits of these two proposals. Then I propose the replacement of the metaphor of following the traces with the textile metaphor of the carpet which considers connecting as a form of weaving. ${ }^{7}$ Using this metaphor I explore the spatial and temporal threads that make up the tapestry of widespread mining practices among the diamond-seekers of Sierra Leone.

My goal is to show the heterogeneity of mining experiences and the continuity between past and present forms of labour exploitation, and between mining and non-mining activities. I argue that unilinear and teleological hypotheses about the morphogenesis of mining labour 
practices cannot convincingly account for their historical complexity as well as their ability to change and continually adapt to different contexts.

\section{From traces to carpets}

For many historians and anthropologists, explaining the social means connecting events, people, and places by following or tracking the terms of these same relationships. ${ }^{8}$ In practice, there are many ways to implement this approach. For this reason, it is worth considering two proposals ostensibly focused on two very different scales of analysis: the GLH of van der Linden and the microhistory of Ginzburg.

According to van der Linden, GLH is primarily a field of research that deals with the 'description and explanation of the intensifying (or weakening) connections (interactions, influences, transfers) between different world regions. ${ }^{9}$ When referring to 'world regions', this scholar does not mean that GLH should deal only with large-scale analyses and explicitly states that this field of research includes microhistorical approaches. Indeed, he affirms that one of the objectives of GLH is precisely: '[t]o identify the big picture in small details (and vice versa, to discover microrealities in macrospaces)-that is what it is all about! ${ }^{10}$ Given that the distinguishing feature of GLH is not scale, the focus of the aforementioned definition is on the type of connections that global historians discuss. The central concern thus becomes identifying which particular connections or types of relationships and transactions require attention. $^{11}$

GLH is well suited to a wide range of topics. As van der Linden writes: '[ $t$ ]he important thing is that we should follow the traces of interest to us wherever they may lead: across political and geographic frontiers, time frames, territories, and disciplinary boundaries. ${ }^{12}$ It is 
not by chance that this is a recurrent expression in van der Linden's essays. ${ }^{13}$ However, what is meant here by 'following the traces'? More specifically, what is a trace? How should we think about the links between traces? In another essay, van der Linden offers some answers to these questions by proposing an exploratory analysis of the origins of the modern management of labour. ${ }^{14}$ Here the Dutch scholar highlights the limitations of historical perspectives that 'situate the origins of modern labor-management techniques in the first and second industrial revolutions in Western Europe and North America. ${ }^{15}$ Left out from these perspectives are those historical experiences of unfree labour in non-Western contexts (prior to the industrial revolution) that had an important role in shaping the modern management of labour. Taking into consideration the invention of the gang system on sugar cane plantations in seventeenth-century Barbados, and the management techniques developed in Australia in the early nineteenth century to regulate convict labour, van der Linden affirms that 'modern labor management has many roots. ${ }^{16}$ Moreover, contrary to Eurocentric assumptions, some of the most important labour innovations originated in the European colonies, namely, those territories considered to be at the margins of Western industrial development. To van der Linden, therefore, 'following the traces' means identifying the origins of a technique that we assume has changed and, at the same time, has remained recognisable in its historical development and its geographical transfers.

The idea of trying to identify the origins of a phenomenon, however, raises some problems. The concept of 'origin' introduces the possibility of a teleological interpretation of history and an essentialist view of what constitutes a working practice. The underlying idea of origin is that the identity of an object remains more or less the same despite any changes that take place: what changes is in continuity with what it has been and what it will be, so that the origin contains an embryo of its future forms. Talking about the 'origins' of the modern management of labour using the plural (to suggest multiple roots), lowers the risk of the 
assumption of a linear and orientated vision of history. However, it does not prevent misunderstandings that may arise around this concept. ${ }^{17}$

Similar conceptual difficulties are also addressed by Ginzburg when he confronts the theme of following the traces.

In the Preface to Myths, Emblems, Spies, Ginzburg acknowledges that his method is 'much more morphological than historical. ${ }^{18}$ He declares that he came to this conclusion through the study of Morelli's method and after reading Wittgenstein's Remarks on Frazer's "Golden Bough". ${ }^{19}$ Here, Wittgenstein argues that historical explanation "is just a way to collect datatheir synopsis.' Hence, he highlights the possibility of summarising the phenomena in a 'general image that does not have the form of a chronological development.' This general image is what Wittgenstein calls a 'perspicuous representation', that is, a representation that does not establish non-existent and unprovable historical ties-such as those that can be imagined 'between the ellipse and the circle. ${ }^{, 20}$ In line with Goethe's morphology, for the author of the Remarks it is all about seeing connections and searching for intermediate links. $^{21}$

Ginzburg shares Wittgenstein's scepticism regarding naïve evolutionary positions. At the same time, he is sceptical about the possibility of applying his philosophical approach to history. $^{22}$ Ginzburg emphasizes that unlike Wittgenstein, Propp considers morphology a useful tool regard to history. ${ }^{23}$ In Ecstasies, Ginzburg's gratitude to the Soviet formalist is perhaps more evident than elsewhere. Here, the microhistorian begins his analysis by stating that he is searching for the roots of the Sabbath in folk culture. ${ }^{24}$ At the end, however, he comes to the conclusion that what he has tried to analyse is the "matrix of all possible stories. $^{25}$ In this erudite and fascinating pathway, between morphology and history, Wittgenstein apparently ends up in the shadows. However, he still plays a crucial role. 
In Ecstasies, Ginzburg offers an impressive range of comparable cultural phenomena in which there is no single element common to all. Seeking this common element would be unproductive and would limit an analysis either on the synchronic and/or on the diachronic level. In this sense, the Wittgensteinian notion of 'family resemblances ${ }^{\text {,2 }}$ appears to solve the problem faced by Ginzburg: connecting similar phenomena without falling into the essentialist trap of rigidly defining the boundaries of a class or group of examined elements. The use of this notion raises another problem, however. Wittgenstein's anti-essentialism is strictly related to the impossibility of distinguishing what is inside from what is outside, what is on the surface from what is underneath. ${ }^{27}$ But a key assumption of the evidential paradigm, on which the metaphor of the trace is also based, is the denial of the transparency of reality. ${ }^{28}$ As a consequence, access to the truth which underlies the appearances of things-the real author of a painting traced through the details of an ear, or the unconscious desire that lies behind the daily lapses-is necessarily indirect. To use Ginzburg's example, Hippocrates read the symptoms and told the stories of diseases, but 'the disease is, in itself, unattainable., 29 Thus, it is not clear how Ginzburg could reconcile the use of family resemblances with his belief in the existence of a hidden reality that historians should reveal. ${ }^{30}$ It seems that the notion that initially appears to bring Ginzburg closer to Wittgenstein is the one that marks how deeply different they are.

Despite Ginzburg's reasonable concerns, is it possible to take Wittgenstein as a starting point when exploring alternatives to following the traces without resorting to problematic notions such as 'origin'?

There is a textile metaphor employed by the author of Philosophical Investigation that can be of use here. The image of the thread, introduced in $\S 67$, is a typical Wittgensteinian thought-image that can help us to think metaphorically, not only about what holds different things together-sometimes things so far removed from one another as to seem completely 
unrelated-but also to think (in parallel) about multi-causality and plural spatio-temporalities. So, what is a thread? A thread is a set of interwoven fibres. None of the fibres that make up a thread are as long as the thread itself. Some fibres overlap and intertwine with one another, others touch lightly, and some are very far from each other despite being part of the same thread. None, individually, are essential to the thread itself. No one fibre represents the origin. Not all fibres are equal. Some are thin and long, others are thick and short. It is the interweaving of the fibres-their ability to create friction and therefore relationships-that matters.

The image of the thread helps us to think about the multiple connections between different places as well as the polychronism of the events, such as the plurality of time in the mines which is made up of different rhythms or cycles (the long rhythms of capitalism, the life cycles of miners, and so on). In short, this image helps us to represent the plural spatiotemporalities of every specific context, a plurality that defies a teleological interpretation of history as well as the tyranny of a chronological order.

This textile metaphor can be made more complex by imagining that the threads composed of fibres, in turn, make up a temporal carpet (or a tapestry) traversable in different directions: vertically, horizontally and diagonally-just like the carpet described by Ginzburg to explain his evidential paradigm. ${ }^{31}$ As a carpet extends across a surface, this metaphor should help to prevent, at least in part, the temptation to think about hidden truths. In this perspective microhistory can be regarded as a movement of the eye's focus that guided by the actors' perspectives, alternately sees the interweaving of the fibres in a thread, the texture of that portion of the carpet of which that specific thread is part, or a larger part of the whole carpet. There is not a point of view which is, in itself, privileged. It is the specific patterns, textures and variations in colours that, from time to time, direct the focus of the eye. Sometimes a detail may captures our attention, other times it is the whole or that part of the whole that the 
eye of our historical vision can grasp that arouses our interest. However, the detail commands our attention because it is in a particular relation to the whole (or better, a part thereof) and vice versa, not because it reveals in itself something more real or deeper.

\section{Subaltern work in the diamond mines}

At this point, let's examine the practices of the miners working in Sierra Leone - in more detail. In this West African country, the alluvial miners are organised into teams or gangs. The gangs are composed of a variable number of people, usually ranging from a minimum of three to a maximum of about thirty. The number involved depends primarily on the economic resources of the owners of mining licenses, as well as the constraints imposed by the Ministry of Mineral Resources. The gangs are financed by one or more supporters who make available to the boss (the head of the gang or the owner of the mining license) the financial capital necessary for the purchase of mining equipment (shovels, sieves, buckets, etc.) and to cover the direct and indirect costs of mining operations such as purchasing the mining license and remunerating the labour force. The supporters can be bosses or miners who work for themselves. More often than not, they are local diamond traders who decided to invest part of their earnings in the most promising mines. It is not unusual for the wealthiest diamond dealers to fund more than one gang in order to diversify their investment and reduce their risk. It should be noted that the diamond trade in Sierra Leone is mainly controlled by members of the Lebanese community, which has been present in the country for several generations. ${ }^{32}$

There are different types of economic agreements for the distribution of the gains from the sale of diamonds that involve the owner of the mining license, the supporter(s), chiefs and the landowner (that is, the individual holding land rights to the excavation site). In particular, 
there are two main methods or systems for allocating earnings or potential earnings. Before starting operations, the miners and the local actors involved can decide: a) to split, according to precise percentages, the profits obtained by selling any discovered diamonds; or, b) to divide the gravel extracted according to specific portions.

As for the relations between supporters and labourers, there are two prominent kinds of agreements. The 'contract system' or 'wage system' is, in fact, the main form of payment in the small-scale mines-those in which gem-seekers are authorized by the Ministry to use machines such as excavators, hydraulic pumps and other mechanised machines. In this case, each miner employed as a labourer receives a fixed level of remuneration. ${ }^{33}$ Those who accept this agreement with the boss waive any other benefits and any percentage of the diamonds discovered.

Alternatively, the 'supporting system' or 'tributing system' is a form of compensation prevalent among artisanal miners; that is, miners who use artisanal technologies such as buckets, shovels, and sieves to find diamonds. In this case, the labourer receives two or three cups of rice and a small monetary reward for each day worked. ${ }^{34}$ Each miner is then also entitled to a percentage of each diamond discovered. In this system of distribution, typical ratios are: 50-50; 60-40; 70-30; and 80-20. For example, a supporter makes an agreement with a landowner. After a period of negotiation, the two parties agree on an 80-20 split. This means that $80 \%$ of the money earned by selling the diamonds will go to the supporter while the remaining $20 \%$ will go to the landowner. In the event that the supporter has negotiated an agreement based on a percentage share with the labourers, they will have to split their $80 \%$ with them. If the miners choose, for example, a ' $60-40$ ', then $40 \%$ of the money generated from the sale of diamonds, minus the fee for the landowner and other expenses incurred to the license owner, goes to the gang. The members of the gang, in turn, split this into shares. 
Usually, the division of labour occurs in equal parts. It should be emphasised that each miner may also receive some additional benefits (e.g., cigarettes and medicine) from their supporter.

These last two types of arrangements-the contract or wage system and the supporting or tributing system-can take hybrid forms. This is more evident at the level of small-scale extraction. The supporter can agree to a system of remuneration based on fixed payment and yet behave as a patron of the tributing system by providing benefits and food. A 'hybrid system' assumes that the supporters have the ability to take on a greater amount of expenditure than those who adhere to the standard agreements of the contract system. However, this has a double advantage: on the one hand, labourers are excluded from any ownership rights over the diamonds recovered in the pits, which is the benefit of the contract system for supporters. On the other, it builds a relationship of loyalty and trust with labourers, which is the primary objective of the tributing or supporting system. In this way, the supporter can prevent thefts and increase worker productivity.

Finally, miners can decide, in particular circumstances, to divide the extracted gravel rather than splitting the money from diamond sales. This system is often used when, for example, the license owner or the supporter does not have enough money to complete mining operations over the entire area at its disposal. In this case, they may decide to engage other bosses and dividing the land into as many parts as there are bosses. Instead of paying a 'sublease', each boss offers a portion of their gravel to the boss/licence owner. Only infrequently is this system used between a supporter and their labourers. ${ }^{35}$

To sum up, it can be said that these agreements are attempts to distribute earnings or potential earnings among the parties involved in the extractive processes taking into account the risks, and hierarchies, as well as the economic expectations of each miner. In other words, they are practical attempts to find a flexible but carefully predetermined balance between available resources and social positions in order to avoid possible tensions and conflicts 
among workers and facilitate the operation's success. But how to explain the morphogenesis of the different systems of compensation and distribution of gains that coexist in this specific working context? Instead of seeking an explanation by tracking the stages of development of the mining industry, I outline from within a field of action that is a spatial and temporal carpet without defined margins or origins. For this reason, the following account is only one possible way to describe this carpet and unravel the knots and fibres that comprise it. At the same time, this sort of unravelling in part follows the contingent logics of the internal intertwining and, therefore, does not proceed randomly.

Given the enormous complexity of this subject, in what follows I focus on key aspects of the colonial history of Sierra Leone's mining industry. In so doing, I endeavour to tie together possible spatio-temporal fibres of analysis to shed light on current mining practices. My intent is to tease apart mining contexts and practices to show the heterogeneity of mining experiences, the resemblances between past and present forms of labour organisation, and the continuities between mining and non-mining activities.

\section{The international diamond monopoly and mineral discoveries in Africa}

A spatio-temporal fibre key to understanding the context of diamond mining in Sierra Leone is the one that stretches across the history of the monopoly developed around this mineral and the history of geological discoveries on the African continent. The monopoly was established by De Beers Consolidated Mines in the late nineteenth century. De Beers took control of the main South African mines and established a sales agreement with the Diamond Syndicate, an organisation of diamond traders operating out of London. ${ }^{36}$

Until the 1920s, South African mines were the main producers of diamonds in the world. This primacy, however, was questioned when several other deposits were discovered 
elsewhere on the African continent. Deposits in the Belgian Congo were discovered in 1909 but extractive operations began only in 1913 when the Belgian company Forminieré obtained an exclusive mining concession. The discovery of deposits in the southern region of Congo activated the Portuguese exploration in neighbouring Angola. The Companhia de Diamantes de Angola was founded in 1917 and immediately afterward obtained an exclusive concession for fifty years ${ }^{37}$ that lasted until the early 1970 s. $^{38}$

In 1924, a number of engineers employed by Forminieré, including Chester Betty and C. W. Boise, founded the Consolidated African Selection Trust (CAST) to extract diamonds discovered in the Gold Coast a few years earlier. CAST created a subsidiary in the mid1930s-the Sierra Leone Selection Trust (SLST)-to extract diamonds discovered in Sierra Leone in 1930. This discovery, in the eastern region of Sierra Leone, activated the search for diamondiferous deposits in neighbouring French Guinea. Here, extraction was carried out by a French company, Songuinex, controlled by CAST. Between the 1930s and mid-1940s other significant discoveries were made in Liberia, the Ivory Coast and Tanganyika. ${ }^{39}$

In response to these findings and the concomitant international economic crisis of the 1930s, De Beers refined its monopoly by convincing the world's main diamond producers to sell their output to the Central Selling Organization (CSO), an umbrella organisation created in 1934 by Ernest Oppenheimer, chairman of De Beers. The CSO realised the dreams of the managers of De Beers for a single channel for the distribution and sale of diamonds from all around the world. In this way, it was possible to maintain high profits as the diamond industry depended (and still does) on strictly controlling the amount of gems available on the market at any particular time..$^{40}$

The discovery of Sierra Leone's alluvial diamond deposits created considerable anxiety for De Beers. ${ }^{41}$ These diamonds were, on average, of a high quality, and suitable for the jewellery industry or for economic investment. During the interwar period there was much uncertainty 
about marketing opportunities for this type of gem. For this reason, De Beers reduced its production-to the point of closing down some of its major mines-with the intention of waiting to sell the accumulated reserve in better times. In reality, between the $1920 \mathrm{~s}$ and 1930s the market for industrial diamonds dropped but remained fairly robust for gemstones. Although CAST joined CSO and slightly reduced its operations, it continued its mining operations in West Africa to support the war efforts of the Allies. ${ }^{42}$ Thus, the company took advantage of the strong demand for diamond jewellery before the Second World War and, during and after the war, took advantage of the demand for industrial diamonds. ${ }^{43}$

\section{Monopolisation and illegalisation of artisanal mining in Sierra Leone}

In Sierra Leone, mineral explorations began around the 1920s. At the end of the First World War, the British government promoted geological surveys in several African territories of the Empire in order to locate mineral resources for military purposes. Between 1919 and 1922, Frank Dixey conducted the first geological surveys of Sierra Leone, but with meagre results. $^{44}$

A few years later, thanks to the efforts of the Director of the Geological Survey of the Gold Coast, the Colonial Office decided to resume geological investigations in Sierra Leone. This time colonial officers were looking for resources to strengthen the weak economy of the colony which was mainly based on agricultural exports (in particular, kola nuts and palm kernel). With this aim, geologist Norman R. Junner was sent to Sierra Leone in 1926 . He found mineral deposits of platinum, chrome, ilmenite, rutile, gold and iron. In 1930, during a survey in Kono District, Junner and his colleague John D. Pollet discovered the presence of diamonds. 
The Anglo-American mining company CAST was informed of the discovery a year later by Junner-who played an important role in making connections between the mines of Sierra Leone and those of Gold Coast. CAST had been working for several years in the Gold Coast, extracting diamonds in Atwakia. Its engineers immediately realised the importance of Junner and Pollett's discovery. In 1934, CAST created a subsidiary, the Sierra Leone Selection Trust (SLST), that obtained exclusive rights from the Government of Sierra Leone to explore and extract diamonds found all over the territory for a period of ninety-nine years. ${ }^{45}$

From the Gold Coast, the managers of SLST imported experienced workers, engineers, and managers. From the beginning, these managers knew that they would soon face a serious problem: illegal mining. In order to prevent the illicit extraction and trafficking of gemstones, they took action to try and control the territory and its population. Restrictive measures on people's movements were first put into effect in 1936. To enter Kono District, for example, it was necessary to obtain a special permit: the entry of "strangers" without official authorisation was banned or severely restricted. ${ }^{46}$

By the 1950s, however, the reputation of Sierra Leonean diamonds had spread around the world. The strict measures of control over the territory and the threat of arrest for possession of diamonds and mining equipment were not sufficient to curb the arrival of migrants, especially from the neighbouring regions of West Africa (including French Guinea, Liberia, Gambia, Nigeria, Gold Coast, Mali and Mauritania). The movement of African miners to the company's protected areas went on day and night. ${ }^{47}$ The monopoly and the legalization of artisanal mining certainly had a profound impact on the technical and organizational choices of African miners. The miners aimed for the most superficial deposits requiring the digging of only shallow pits in order to extract the gravel containing diamonds in the shortest time possible, that is, before the police and SLST security forces might be alerted to their presence. It is likely that in, some cases, miners preferred to share the gravel on the spot, without 
waiting for the completion of gravel washing. This important operation could be carried out quietly, once the material was transported to less visible and more protected areas. ${ }^{48}$

In 1955, SLST made an agreement with the Government to give up their monopoly while preserving some of the most productive mineral areas. In return, the company obtained lavish compensation from the Government. The latter pledged to intensify efforts to combat lawlessness. At the same time, starting in 1956, Sierra Leonean miners were allowed to extract precious gems through a licensing system called the Alluvial Diamond Mining Scheme (ADMS). For everyone else, the only alternative was to abandon or continue illegal mining, seeking the protection of the local authorities. ${ }^{49}$

In 1959, SLST created the 'Contract Mining Scheme.' With this, the company committed itself to buying diamonds from miners who dug and sold diamonds recovered in the concession areas abandoned after the 1955 agreement, that is, those areas considered unproductive for the use of large-scale mining technology. ${ }^{50}$ The scheme, described as 'a form of tributing inside the SLST lease and controlled by SLST, ${ }^{51}$ lasted until 1970 when SLST was nationalised by the independent government of Sierra Leone and renamed the National Diamond Mining Company. ${ }^{52}$ Before turning attention to 'tributing', it is useful to examine the interweaving of temporal fibres to shed light on labour relations in the mines of Sierra Leone.

\section{Labour relations in (and around) the mines}

Working relations among the miners employed in Sierra Leone exist in relationship with, and against, the background of the historical context of the global diamond industry and of Sierra Leone. Although slavery was outlawed in the colony-Freetown was established in 1808 as a settlement for freed slaves transported from North America-in the Protectorate of 
Sierra Leone the practice remained active and unhindered until $1928 .^{53}$ The British promoted a smooth and gradual transition toward abolition, ${ }^{54}$ convinced that a sudden change of local customs would cause unmanageable conflicts. Thus, the Forced Labour Ordinance of 1932which was enacted following the amendment of the 1930 Geneva Convention on Forced Labour-authorised chiefs to employ labour for public works or for specific personal services. ${ }^{55}$ In some regions of the Protectorate, forms of forced labour persisted until the late 1950s. In fact, it was only after the 1955 riots and the subsequent investigation by the Cox Commission that in 1956 the Government decided to enact the Prohibition of Forced Labour Ordinance. The Commission noted in its report that the right of chiefs to force young people to perform unpaid work was a major cause of the riots. However, while the 1956 Ordinance repealed forced labour, it still gave the chiefs some prerogatives on the use of unpaid community labour. $^{56}$

This was the context in which early labour relations in the mines emerged. In January 1928, men and women previously considered servants or slaves became formally 'free'. In a 1931 report, ${ }^{57}$ the British geologist Pollet included images of large groups of people waiting to obtain employment in the alluvial gold mines. The first companies to obtain mining licenses for the exploitation of gold deposits-the British Coastal Exploration Syndicate Limited and the Messrs Maroc Limited ${ }^{58}$-typically offered monthly jobs. Some miners were put on contract and paid according to the amount of work done. ${ }^{59}$ Taking into account the recent abolition of slavery it is not surprising that the engineer in charge of company's camp found 'there [were] always more applicants for work than he can employ. ${ }^{60}$ On average, about half of the miners came from villages neighbouring the mining sites. The remainder was mainly made up of men from different regions of the Protectorate: Mende, Limba, Temne and Koranko were the most well-represented ethno-linguistic groups. Employers generally considered people from further afield more reliable than those coming from nearby villages. 
According to the reports of colonial officials, the local workers did not come to the mines on a regular basis, and often devoted part of their working day to pursuing other activities such as trading, farming, or hunting. ${ }^{61}$ Production costs and international uncertainties over the trends in commodity prices pushed the gold mining companies to keep wages as low as possible. Thus, in many instances the local workforce showed preference for the often more lucrative agricultural work in the fields. Some mines used 'feed money' ${ }^{62}$ to compensate miners in an attempt to improve stability of their labour force. In the early 1930s, for example, the Messrs Maroc sold rice to its workers at cost in order to keep down the prices of basic commodities in nearby villages. By selling rice to their miners at no profit to themselves, the company sought to discourage harvesting in the fields and to encourage working in the mines.

SLST made similar choices a few years later in the diamond district of Kono. Initially, the company managers brought in skilled labour from Nigeria, and especially from the Gold Coast in order to teach the local workforce extraction techniques adopted in the CAST diamond mines at Atwakia. ${ }^{63}$

Although SLST offered better payment terms than other companies, in Kono District, the sale of palm kernels was, at times, less arduous and better paid than work in the diamond mines. The problem of local labour force recruitment became most acute during the harvest season, between January and February. ${ }^{64}$ In 1937 in particular, the demand for agricultural production increased due to the expansion of the international cosmetic industry. At the same time, there was a shortage in rice production, resulting in part from the increased migrant population present in the mining areas and the reduction of agricultural labour devoted to this staple. To address this specific problem, SLST imported quantities of rice that it sold to the company's employees at a regulated price. In exchange for rice, however, the workers had to give up any increase in wages. 
It should be noted that this type of non-wage benefit was not simply a reaction to the specific difficulties of that period. Rather, it was part of a broader and paternalistic labour policy which aimed to increase productivity, and minimise theft and illicit mining. ${ }^{65}$

\section{The supporting system in tin, gold, and diamond mining}

The diamond industry of Sierra Leone did not emerge in isolation from other extractive industries. Its history is intertwined from the moment it emerged with the simultaneously emergent gold mining industry. This, in turn, was interwoven with other mining and nonmining experiences in West Africa.

After the first discoveries of alluvial gold deposits, between mid-1920s and early 1930s, the colonial government of Freetown preferred to grant mining licenses to large-scale British operations. ${ }^{66}$ The uncertain nature of the alluvial deposits, however, was problematic for large-scale investors and in fact favoured small-scale miners. Many companies went bankrupt after a few years and others took their place and experienced mixed results. ${ }^{67}$

Early small-scale miners managed to obtain licenses for gold extraction in 1934. They were mostly made up of educated members of the Krio community of Freetown who obtained mining licenses as individuals or syndicates. ${ }^{68}$ Among them, there were a few goldsmiths, moneylenders and professionals, but no one with mining experience. ${ }^{69}$ Most probably the only ones who possessed some knowledge of gold were A. B. Sillah and J. A. Lasite, two known Freetown goldsmiths. Before becoming miners themselves, it is said that they bought gold from illicit dealers. ${ }^{70}$ Among small-scale miners, members of the Lebanese community were the most successful. They entered into the mining industry in 1935, just after the Krio. The Lebanese were mainly traders and, as far as is known, also had no mining experience. They were able, however, to address the risks of this sector by employing local miners as 
tributors. ${ }^{71}$ As under the abusa system adopted by gold miners in the Gold Coast, ${ }^{72}$ tributors did not receive a salary, but a share of the gold. Among these workers there were often men who had worked for European companies. Indeed, tributing offered the chance to earn more than employees of the large operations. From the point of view of patrons, one of the main advantages of the tributing was that workers were only paid if the mine produced gold. In addition, the supervision of a patron was not always necessary. Tributors self-organised and patrons could carry on other professional activities. ${ }^{73}$ It is clear, then, that both Krio and Lebanese learned the basics of gold mining from their 'boys' and, particularly, from those who had worked for European companies. ${ }^{74}$

By analysing the reports of the colonial government's Geological Department, van der Laan argues that tributing was first introduced in the gold mines in 1935 by the Gold and Base Metal Mines of Nigeria. ${ }^{75}$ This company mainly mined tin and other base metals in northern Nigeria. The international economic crisis of the early $1930 \mathrm{~s}$, the resulting drop in the price of tin, and the rising price of gold were some of the reasons that likely prompted this company to explore the opportunities offered by the alluvial deposits recently discovered in Sierra Leone. ${ }^{76}$ In Nigeria, as in other West African colonies, tributing was a common practice adopted especially in alluvial gold and tin mining. ${ }^{77}$ Unsurprisingly, the Gold and Base Metal Mines of Nigeria replicated in Sierra Leone what had been common in Nigeria.

The small-scale miners of the Shamel Brothers group were among the first to imitate the methods of work, recruitment, and payment of the Gold and Base Metals of Nigeria. Though lacking mining experience, this partnership of Lebanese traders came to employ more than a thousand men in 1936. The following year, van der Laan notes, 'all companies derived part of their gold from tributors and many small miners relied entirely on them. ${ }^{, 78}$

The official production of gold began to decline during the Second World War but the number of migrants in the diamondiferous south-eastern area of Sierra Leone grew 
considerably after the war. Among these gem seekers were men with experience in gold mining, like Alhaji Sesay. Sesay was a gold miner in the northern part of Sierra Leone from 1934 until 1941, the year he was conscripted into the army. In 1945, he resumed mining. In 1956, he began to look for diamonds by taking advantage of the licence scheme for the artisanal extraction of diamonds just introduced by the government. ${ }^{79}$ Sesay's professional trajectory was not unusual. Many miners arrived in the diamond areas during the 1950s, particularly the Temne, had worked in the gold mines of the northern region. Others, like the Mandingo people ${ }^{80}$ came mainly from the French colonies, in particular, from Guinea where there were both gold and diamond mines. ${ }^{81}$ Among the ranks of the gem seekers there were also many Kono and Mende people, some of whom possessed knowledge and technical skills acquired while working for SLST. ${ }^{82}$

As a result, between the gold and diamond mining sectors there were numerous adaptations and exchanges derived from the local and transnational labour force, ${ }^{83}$ and also the local entrepreneurs, particularly the Lebanese merchants who played a crucial role in the development of the Sierra Leonean mining industry. ${ }^{84}$

\section{Sharing and tributing in farming and mining}

To understand the morphogenesis of the practices of diamond miners, it is necessary at this point to extend our gaze towards working and agreement practices that go beyond the mines. In particular, striking 'family resemblances' exist between farming and mining. To examine them, it is useful to focus on gold mining.

Though pre-colonial mining in Sub-Saharan Africa is, to say the least, as old as the Malian (from c. 1230 to c. 1600) and Ashanti Empires (from c. 1700 to 1957), ${ }^{85}$ in the territory of Sierra Leone there is no clear historical evidence of extractive activities predating colonial 
discoveries. ${ }^{86}$ Van der Laan's historical reconstruction of how tributing may have been introduced in Sierra Leone's mines presupposes an exogenous (and unilinear) movement of practices and ideas. However, if tributing was immediately accepted and rapidly became a widespread practice among Sierra Leone's miners, this has to do with the fact that it was a practice culturally recognised by both transnational and local labourers. That is to say that van der Laan's hypothesis, does not consider the possibility that miners' practices, particularly at the level of artisanal or small-scale operations, involved interwoven and multiple historical and geographical encounters between working experiences and cultural norms across this West African region. To clarify, it is worth briefly exploring and further unravelling other spatio-temporal threads which can shed light on cultural practices common in many rural societies of the Upper Guinea Forest. ${ }^{87}$ To this end, two practices deserve particular attention: the abusa system and the tutorat.

As historian Raymond Dumett points out in his work on the development of the Gold Coast's mining industry at the end of nineteenth century, European companies based in Wassa had difficulty recruiting local workers. ${ }^{88}$ Often, they preferred to employ unskilled workers from Liberia and from Sierra Leone's coasts. ${ }^{89}$ Local Wassa people, in fact, preferred to look for gold using traditional methods tested locally for centuries by generations of African miners, ${ }^{90}$ or to alternate "whites" jobs" in the mines with agricultural activities in the villages. Therefore, their presence was not always guaranteed. In Wassa, the solution for the mining companies to the so-called "native labour problem"91 "was to hire Akan "tributors" based on the traditional abusa share system. ${ }^{92}$

In the Twi language, abusa means 'one-third', but in the twentieth century, among Gold Coast farmers engaged in the production of cocoa, abusa became a way to refer to the portion of the harvest that the supplier of labour had to offer to the supplier of the land. ${ }^{93}$ Abusa is thus a form of tribute related to the traditional duty of offering a portion of the product 
obtained from the ground, or from the forest to the rulers and local traditional authorities. ${ }^{94}$ In this sense, the abusa system for gold miners was mainly an adaptation of the share cropping system. ${ }^{95}$ In the late nineteenth century, this system was successfully applied and accepted by Gold Coast's miners and European companies because it seemed to provide benefits for all parties. Tributors held a third, or even a half of the material extracted. In this way, they often managed to earn more than they could as tributors of the chiefs and of local stool holders. The remainder belonged entirely to the company or it was further divided with local traditional authorities. Thus, in Wassa, the gold company was not required to take care of labourers' housing and feeding. ${ }^{96}$ Besides that, it did not have to spend money to import labourers from Liberia nor did it have to worry about the organisation and recruitment of miner gangs. ${ }^{97}$

To return to the case of Sierra Leone, we cannot exclude the possibility that the abusa system-or similar tributing systems based on patronage relationships such as the tutorat ${ }^{98}$ had been, at different times, a practical model from which Sierra Leone's miners drew ideas and solutions for organising their work. Once again, it is worth stressing the crucial role played by migrant workers in translating such experiences from one context to another.

However, it is also possible that local miners, faced with the uncertainty of alluvial deposits and the danger of being arrested by the colonial security forces, adopted and developed existing local sharing systems which resulted in arrangements similar to those of abusa. In this regard it should be noted that the traditional Akan law of the Gold Coast has many family resemblances with the customary tenure law common to most of the territory of Sierra Leone. In both contexts, the concept of ownership is different from that of private property. ${ }^{99}$ In many regions of West Africa, land is owned collectively and is managed by traditional authorities. Because of this, one of the privileges still retained by Paramount Chiefs $^{100}$ of Sierra Leone is to receive tributes from both foreign residents and from various subjects who occupy the land over which they rule. Thus, Paramount chiefs are entitled to 
receive as a tribute, portions of the harvested rice and palm oil produced in their chiefdoms, as well as portions of the game captured and the trees cut in forests. Paramount Chiefs also have the right to receive one-third 'of all rents paid by non-natives in respect of lands occupied or leased in the chiefdom. ${ }^{101}$ Miners are not exempt from this type of contribution which is well-regulated.

As it might be clear from the discussion above, it is not possible to fully understand the labour practices of artisanal miners without taking into account the social institutions that shape relations between 'autochthons and strangers', ${ }^{102}$ 'first comers and later comers', ${ }^{103}$ or between 'landowners and strangers' in the Upper Guinea Forest. ${ }^{104}$ As Bolay points out, the artisanal mining sector is intimately related to soil property and strongly structured by autochthony relations.' $^{105}$

In the rural societies of this extended West African region, the tutorat 'regulates both the transfer of land rights and the incorporation of the "strangers" in the local community., 106 Strangers, as 'later comers', gain access to the land from the landowners ('first comers') who then become their sponsors or tuteurs. In return, strangers show their gratitude by offering, for example, agricultural products or monetary compensation for the use of land. They also contribute to the reproduction of the community social order. ${ }^{107}$ Therefore, tutorat is a kind of patron-client relationship that regulates the rights and obligations between landowners and strangers on the basis of the principles of a local moral economy. ${ }^{108}$ In Ivory Coast, for example, the tutorat played a significant role in regulating migrant access to the cocoa and coffee farms which developed in the $1920 \mathrm{~s} .{ }^{109}$ In different ways, past and present migrants working in the farms or in the artisanal small-scale gold mines of Guinea, ${ }^{110}$ Mali, ${ }^{111}$ Burkina Faso, ${ }^{112}$ and Benin ${ }^{113}$ have established mentoring relationships, particularly, with residents.

Tutorat and the 'landlord-stranger system' have several family resemblances. ${ }^{114}$ Concerning Sierra Leone's diamond mines, Jean-Pierre Chauveau and Paul Richards have 
stressed how 'Land-owning lineages are essential partners in alluvial operations. ${ }^{115}$ For this reason, diamond miners divide part of their earnings with them.

To return to van der Laan's unilinear and exogenous hypothesis, it certainly cannot convincingly account for the historical complexity of these social practices as well as their ability to change and constantly adapt to different contexts. The tributing system, like all social practices, has a social life: it changes over time and it adapts to changing cultural, political, and historical scenarios. ${ }^{116}$

\section{Conclusion}

As noted by the anthropologist Michael Jackson, spinning, weaving, binding, threading braiding and knotting are at same time some of the oldest techniques and metaphors known by human beings. ${ }^{117}$ No wonder that it in many societies around the world social relations are conceived as 'bonds, ties or strings, while wider fields of relationship are compared to networks, webs, and skeins, or the warp and woof of woven cloth. ${ }^{, 18}$ I have endeavoured to show how textile metaphors are also good to think through non-linear causal relationships, as well as the spatial-temporal entanglement specific to each historical and cultural context. ${ }^{119}$ The historical and anthropological analysis of diamond miners' working practices shows that there is not an origin that can explain their subsequent development. There is also no single causal explanation. If anything, what these practices reveal are the many spatial and temporal twists that connect, in complex ways, events, people and contexts. In other words, the practices of the miners appear to be an assemblage of heterogeneous and, in some respects, conflicting elements. This assemblage is not the result of an omniscient hand that has wisely 
chosen and ordered the temporal threads according to a precise final design. On the contrary, it is the result of a number of incongruent, and sometimes contradictory interventions.

If we want to bring our textile metaphor to another level, we may ask ourselves who weaves the threads and who makes the carpet. The answer is that there is a multiplicity of social actors, each with different levels of ability and power to act.

In the mines of Sierra Leone, the exchange of knowledge and experiences among workers, company executives, and other social actors involved in this industry (e.g., chiefs and colonial rulers), has contributed significantly to the hybridisation of mining practices. This helps to understand their innumerable 'family resemblances'. ${ }^{120}$ Indeed, I have suggested that these practices come not only from different types of extractive contexts (for example, gold and tin mining), but also from non-mining contexts such as agriculture. The tributing system described by van der Laan in the case of gold mining has strong resemblances with those common in diamond mining. In a similar vein, the share crop system has significant resemblances with the practice of dividing extracted material between miners, companies and traditional authorities in both gold and diamond mining.

Each idea or mining practice is a particular combination of knowledge and experiences that has changed in response to specific problems embedded in specific historical and political situations. To emphasize the contingency of encounters between these practices and experiences is to recognise that capitalism cannot be thought to have a single repeatable model of development. ${ }^{121}$ That is to say that diamond miners' practices are the unpredictable result of the continuous efforts of the global mining industry to articulate different modes of production. The carpet is the living metaphor of this spatio-temporal assemblage with no origin. 


\footnotetext{
${ }^{1}$ I would like to thank the participants of the writing workshop "Translocal- and microhistories of global labour" organised by Christian G. De Vito and Anna Geritsen at the University of Warwick (23-24 January 2015), as
} well as Toby Boraman and Emma Battell Lowman for comments and criticisms. I discussed some thoughts contained in this paper during the Fifth Annual Conference organised by IGK Work and Human Lifecycle in Global History in Berlin the $9^{\text {th }}$ of July 2014. For this reason, I thank re:work's staff and fellows for their useful comments. The final stage of writing this paper has greatly benefited from a fellowship granted by the Italian Academy for Advanced Study, Columbia University, New York (Spring 2015).

${ }^{2}$ On the difficulties of writing about connections, see Frederick Cooper, 'Back to Work: Categories, Boundaries and Connections in the Study of Labour', in Racializing Class, Classifying Race. Labour and Difference in Britain, the USA and Africa, eds. Peter Alexander and Rick Halpern (London, 2000), pp. 213-235.

${ }^{3}$ see De Vito (in this volume).

${ }^{4}$ Cooper, 'Back to work', p. 213.

${ }^{5}$ Since the end of the civil war (1991-2002) the extraction of this mineral has come from two types of sources in this West African country: alluvial and kimberlite deposits. The alluvial diamonds are extracted mainly with artisanal technologies such as shovels and sieves (artisanal level) or with machinery such as hydraulic pumps, bulldozers and mechanised sieves (small scale level). In 2005 it was estimated that there were more than 200300,000 people engaged at these two levels of extraction (artisanal and small-scale mining). Conversely, diamond extracted from the kimberlite rock requires large-scale technology usually owned by foreign mining companies capable of huge investments. As a consequence of high-capital investment in technology, large-scale mining do not employ as much labour as artisanal and small-scale mining.

These differences in technologies and investments largely reflect the characteristics of the different types of deposits. From a geological point of view, kimberlite deposits are ancient volcanic conduits which can be localised in specific areas. Once experts have identified these deposits it is possible to estimate their productivity. On the contrary, alluvial diamonds are scattered underground over vast areas. Ascertaining their location (or quantity) is far from simple.

${ }^{6}$ Carlo Ginzburg, Miti Emblemi Spie. Morfologia e Storia (Torino, 1986).

${ }^{7}$ As noted by the philosopher Vittorio Morfino, the Latin etymology of the word "to connect" (connectere) refers to the meaning of "to weave" (Vittorio Morfino, Il Tempo della Moltitudine. Materialismo e Politica prima e dopo Spinoza (Roma, 2005), p. 29). 
${ }^{8}$ Bruno Latour reminds us that the etymology of the word 'social' has roots in 'following' (Bruno Latour, Reassembling the Social. An Introduction to Actor-Network-Theory (Oxford, 2005).

${ }^{9}$ Marcel van der Linden, 'The Promise and Challenges of Global Labour History', International Labor and Working Class History, 82 (2012), 57-76, cit. p. 62.

${ }^{10}$ Ibid., p. 62.

${ }^{11}$ Andreas Eckert, 'What is Global Labour History Good For?', in Work in a Modern Society. The German Historical Experience, ed. Jürgen Kocka (New York-Oxford, 2010), pp. 169-181.

${ }^{12}$ van der Linden, 'The Promise and Challenges', p. 62.

${ }^{13}$ Christian G. De Vito, 'New Perspectives on Global Labour History. Introduction', Workers of the World, 3, 1 (2013), 7-31, see p. 16.

${ }^{14}$ Marcel van der Linden, 'Re-constructing the Origins of Modern Labor Management', Labor History, 51, 4 (2010), 509-522.

15 Ibid., p. 510.

${ }^{16}$ Ibid., p. 516.

${ }^{17}$ Different philosophers criticise the notion of origin (i.e. Louis Althusser, Lire le Capital, Vol. 1 \& 2 (Paris, 1965); Michael Foucault, Language, Counter-Memory, Practice: Selected Essays and Interviews (Ithaca, NY, 1980).

${ }^{18}$ Ginzburg, Miti, Emblemi, Spie, p. xiv.

${ }^{19}$ Ludwig Wittgenstein, Remarks on Frazer's “Golden Bough (Retford, 1979).

${ }^{20}$ Carlo Ginzburg, Storia Notturna. Una Decifrazione del Sabba (Torino, 1989), cit. p. xxix. Cf. also Ludwig Wittgenstein, Philosophical Investigations (Oxford, 1953), esp. §122.

${ }^{21}$ For a comparison between Goethe's and Wittgenstein's philosophy, see Goethe and Wittgenstein. Seeing the World's Unity in its Variety, eds. Fritz Breithaupt, Richard Raatzsch, and Bettina Kremberg (Frankfurt am Main, 2003).

${ }^{22}$ Ginzburg, Storia Notturna, p. xxix

${ }^{23}$ Ginzburg, Miti, Emblemi, Spie, p. xv.

${ }^{24}$ Ginzburg, Storia Notturna, p. xxviii.

${ }^{25}$ Ibid., p. 289.

${ }^{26}$ Wittgenstein clarifies this notion with an example. What do board-games, card-games, ball games, and the Olympic Games have in common? The answer Wittgenstein gives is apparently simple: 'If you look at them you 
will not see something that is common to all, but similarities, relationships, and a whole series of them at that' (Wittgenstein, Philosophical Investigations, p. 31). As among family members, we can see similarities between the various games, or rather 'a complicated network of similarities overlapping and criss-crossing: sometimes overall similarities, sometimes similarities of detail' (Ibid., p. 32). However, there is nothing that unites them all under a single definition.

${ }^{27}$ Giuseppe Di Giacomo, ‘Art and Perspicuous Vision in Wittgenstein's Philosophical Reflection', Aisthesis. Pratiche, linguaggi e saperi dell'estetico, 6, 1 (2013), 151-172.

${ }^{28}$ Ginzburg, Miti, Emblemi, Spie, p. 170.

${ }^{29}$ Ibid., p. 169.

${ }^{30} \mathrm{cf}$. John Martin, 'Journeys to the World of the Death. The Work of Carlo Ginzburg', Journal of Social History, 25, 3 (1992), 613-626, esp. p. 623.

${ }^{31}$ Ginzburg, Miti, Emblemi, Spie, p. 184.

${ }^{32}$ Laurens, H. van der Laan, The Lebanese Traders in Sierra Leone (The Hague-Paris, 1975).

${ }^{33}$ This is usually between 5,000 and 10,000 Leones, the equivalent of about 2-3 USD-for a working day of about eight hours.

${ }^{34}$ This reward can vary, usually, from a minimum of 500 to a maximum of 3000 Leones (about 1 USD a day).

${ }^{35}$ The miners without a license can be organized in so-called 'gado gangs', that is, in groups of miners who equally share the extracted gravel. The gain of each is related to the probability of finding diamonds in ones' own pile of gravel. For more details, see Estelle Levin, 'From Poverty and War to Prosperity and Peace? Sustainable Livelihoods and Innovation in Governance of Artisanal Diamond Mining in Kono District, Sierra Leone', MA thesis, University of British Columbia, 2005.

${ }^{36}$ Edward J. Epstein, The Death of the Diamond. The Coming Collapse in Diamond Prices (London, 1983).

${ }^{37}$ J. L. Burke, 'A Short Account of the Discovery of the Major Diamond Deposits', Sierra Leone Studies, 12 (1959), 316-328, esp. p. 322.

${ }^{38}$ Peter Greenhalgh, West African Diamonds 1919-1983. An Economic History (Manchester-Dover, 1985), p. 24.

${ }^{39}$ Ibid.

${ }^{40}$ Colin Newbury, The Diamond Ring. Business, Politics, and Precious Stones in South Africa, 1867-1947 (Oxford, 1989).

${ }^{41}$ Greenhalgh, West African Diamonds, p. 61. 
${ }^{42}$ Raymond E. Dumett, 'Africa Strategic Minerals During the Second World War', Journal of African History, 26 (1985), 381-408.

${ }^{43}$ Greenhalgh, West African Diamonds, pp. 27-33.

${ }^{44}$ Lorenzo D'Angelo, 'The Art of Governing Contingency. Rethinking the Colonial History of Diamond Mining in Sierra Leone', Historical Research, 89, 243 (2016), 136-157.

${ }^{45}$ Laurens H. van der Laan, The Sierra Leone Diamonds (Oxford, 1965).

${ }^{46}$ Alfred Zack-Williams, Tributors, Supporters and Merchant Capital. Mining and Underdevelopment in Sierra Leone (Aldershot-Brookfield USA-Hong Kong-Singapore-Sydney, 1995), p. 181.

${ }^{47}$ William Reno, Corruption and State Politics in Sierra Leone (Cambridge, 1995), p. 62.

${ }^{48}$ Tilo Grätz interprets the system of sharing clumps of soil containing gold between the miners of Northern Benin as a strategy to reduce the risk of being caught by police before they can split their gains (Tilo Grätz, 'Gold-Mining and Risk Management: A Case Study from Northern Benin', Ethnos, 68, 2 (2003), 192-208). In this case the gold miners prefer to divide the stones and clumps extracted underground rather than the gold actually recovered. As far as we can tell from the brief description provided by Grätz, the method chosen by the miners is apparently simple: half of the stones potentially containing gold is taken by the chief d'equipe and the other half is divided among his secrétaire and other workers (Tilo Grätz, 'Moralities, Risk and Rule in West African Artisanal Gold Mining Communities. A Case Study of Northern Benin', Resource Policy, 34 (2009), 1217).

\footnotetext{
${ }^{49}$ Reno, Corruption.

${ }^{50}$ Zack-Williams, Tributors, p. 120.

${ }^{51}$ Greenhalgh, West African Diamonds, p. 167.

${ }^{52}$ Zack-Williams, Tributors, p. 123.
}

${ }^{53}$ The Colony of Sierra Leone was founded in 1808 to receive the slaves freed by the British in their fight against the Atlantic trade in human beings. However, the current borders of Sierra Leone were established only in 1896 when the British decided to annex a portion of the African territory surrounding the Freetown Peninsula. While the Colony was ruled under the British legal system, the hinterland was ruled as a British Protectorate and was indirectly controlled though local chiefs (Christopher Fyfe, A Short History of Sierra Leone (London, 1967).

${ }^{54}$ John Grace, Domestic Slavery in West Africa with Reference to the Sierra Leone Protectorate, 1896-1927 (London, 1975), p. 491. 
${ }^{55}$ Richard Rathbone, 'West Africa, 1874-1948: Employment Legislation in a Nonsettler Peasant Economy', in Masters, Servants, and Magistrates in Britain and the Empire, 1562-1955, eds. Douglas Hay and Paul Craven (Chapel Hill-London, 2004), p. 488.

${ }^{56}$ Colonial Office, Sierra Leone: Report for the Year 1956 (London, 1957), p. 74. For an analysis of the impact of these colonial decisions on the agrarian order of the Upper Guinean Forest, and its recent conflicts, see JeanPierre Chauveau and Paul Richards, 'West African Insurgencies in Agrarian Perspective: Côte d'Ivoire and Sierra Leone Compared', Journal of Agrarian Change, 8, 4 (2008), 515-522, and Krijn Peters and Paul Richards, 'Rebellion and Agrarian Tensions in Sierra Leone', Journal of Agrarian Change, 11, 3 (2011), 377-395.

${ }^{57}$ John D. Pollett, Report on the Gold Areas by the Acting Chief Inspector of Mines, Mr. J. D. Pollett: The National Archives (T. N. A.), London, U.K., CO 267/635/11, Enclosure to Sierra Leone Confidential despatch, 12 Oct. 1931.

${ }^{58}$ van der Laan, The Lebanese Traders, p. 145.

${ }^{59}$ Pollett, Report, p. 14.

${ }^{60}$ Ibid.

${ }^{61}$ Ibid.

${ }^{62}$ Ibid, p. 28.

${ }^{63}$ Letter of the Governor D. J. Jardine to W. G. A. Ormsby Gore, 3 May 1938: T. N. A. CO267/665/3.

${ }^{64}$ Greenhalgh, West African Diamonds, p. 125.

${ }^{65}$ Ibid., pp. 127-132.

${ }^{66}$ On the contrary, French administrators favoured artisanal mining in the gold mines of the Haut-Niger (see Sabine Luning, Jan Jansen, and Cristiana Panella, 'The Mise en Valeur of the Gold Mines in the Haut-Niger, 1918-1939', French Colonial History, 15 (2014), 67-86, esp. p. 75.

${ }^{67}$ Martin H. Y. Kaniki, The Economic and Social History of Sierra Leone, 1929-1939, PhD Thesis (Birmingham, 1972), p. 167; van der Laan, The Lebanese Traders, pp. 147-9.

${ }^{68}$ The Krio are the descendants of the 'Liberated Africans' and other ex-slaves rehabilitated in Sierra Leone since the end of Eighteenth Century (Akintola Wyse, The Krio of Sierra Leone. An Interpretative History (Washington, D.C., 1991).

${ }^{69}$ Kaniki, The Economic and Social History, p. 170.

${ }^{70}$ Ibid.

${ }^{71}$ van der Laan, The Lebanese Traders, p. 149. 
${ }^{72}$ Raymond E. Dumett, El Dorado in West Africa: The Gold-Mining Frontier, African Labor, and Colonial Capitalism in Gold Coast, $1875-1900$ (Oxford, 1998).

${ }^{73}$ cf. van der Laan, The Lebanese Traders, p. 150.

${ }^{74}$ Kaniki, The Economic and Social History, p. 171.

${ }^{75}$ van der Laan, The Lebanese Traders, p. 150.

${ }^{76}$ Kaniki, The Economic and Social History.

${ }^{77}$ William Freund, 'Theft and Social Protest Among the Tin Miners of Northern Nigeria', Radical History Review, 26 (1982), 68-86, esp. p. 75; Greenhalgh, West African Diamonds, p. 175; B. W. Hodder, 'Tin Mining on the Jos Plateau', Economic Geography, 35, 2 (1959), 109-122; esp. p. 115; J. H. Morrison, 'Early Tin Production and Nigerian Labour on the Jos Plateau', Canadian Journal of African Studies, 11, 2 (1977), 205216, esp. p. 208.

${ }^{78}$ van der Laan The Lebanese Traders, p. 150; cf. Kaniki, The Economic and Social History, p. 176.

${ }^{79}$ Zack-Williams, Tributors, p. 154.

${ }^{80}$ In Sierra Leone, 'Mandingo' can refer to a wide range of people of different origins (see Chauveau and Richards, 'West African Insurgencies', p. 525, note 19).

${ }^{81}$ Sylvie Bredeloup, La Diams'pora du Fleuve Sénégal. Sociologie des Migrations Africaines (Paris, 2007), p. 71.

${ }^{82}$ van der Laan The Lebanese Traders, pp. 158-9.

${ }^{83}$ Bredeloup, La Diams 'pora.

${ }^{84}$ Caspar D. Fithen, Diamonds and War in Sierra Leone: Cultural Strategies for Commercial Adaptation to Endemic Low-Intensity Conflict, Ph.D. Thesis (London, 1999); see also Reno 1995; van der Laan 1975.

${ }^{85}$ Eugenia W. Herbert, 'Elusive Fronties: Precolonial Mining in Sub-Saharan Africa', in Mining Frontiers in Africa. Anthropological and Historical Perspectives, eds. Katjia Werthmann and Tilo Grätz (Köln, 2012), pp. 23-32; Jan Bart Gewald 'Gold the True Motor of West African History: An Overview of the Importance of Gold in West Africa and its Relations with the Wider World', in Worlds of Debts. Interdisciplinary Perspectives on Gold Mining in West Africa, ed. Cristiana Panella (Amsterdam, 2010), pp. 137-151.

${ }^{86}$ See Kaniki, The Economic and Social History, p. 166. This observation is based mainly on colonial sources. It is worth noting, however, that neither geologists, nor British colonial administrators were interested in investigating pre-existing native extractive activity. Geologists were eager to prove that they were the first to discoverer the deposits. Sometimes, competition led to disputes such as the one between geologists Junner and 
Pollett about who was first to discover a diamond in Sierra Leone. For British colonial officials, documenting any precolonial mining activity risked precluding, or complicating, their creation of a legal apparatus for the exploitation of mineral resources. In Sierra Leone, the first mining ordinance was enacted in 1927 and was based on the assumption that native people had no knowledge or established use of minerals in their lands (Lorenzo D'Angelo, 'L'Arte dello Spossessamento. Un'Archeologia Coloniale del 'Furto' della Terra in Sierra Leone', in I Conflitti per la Terra. Tra Accaparramento, Consumo e Accesso Indisciplinato, eds. Cristiana Fiamingo, Luca Ciabarri, and Mauro Van Aken (Lungavilla, 2014), pp. 177-190).

${ }^{87}$ Jean-Pierre Chaueaveu, Jean-Pierre Colin, Jean-Pierre Jacob, Philippe Lavigne Delville, and Pierre-Yves Le Meur, Changes in Land Access and Governance in West Africa: Markets, Social Mediations and Public Policies (London, 2006).

${ }^{88}$ Raymond E. Dumett, El Dorado in West Africa. The Gold-Mining Frontier, African Labor, and Colonial Capitalism in the Gold Coast, 1875-1900 (Oxford, 1998).

${ }^{89}$ Ibid., pp. 144, 150-1, 222.

${ }^{90}$ Jim Silver, 'The Failure of European Mining Companies in the Nineteenth-Century Gold Coast', Journal of African History 22, 4 (1981), 511-529, see p. 511.

${ }^{91}$ Dumett, El Dorado, p. 144.

${ }^{92}$ Ibid., p. 153.

${ }^{93}$ A. F. Robertson, 'On Sharecropping', Man, 15, 3 (1980), 411-429; A. F. Robertson, 'Abusa: The Structural History of an Economic Contract', Journal of Development Studies, 18, 4 (1982), 447-478.

${ }^{94}$ Dumett, El Dorado, pp. 69, 122.

${ }^{95}$ Silver, 'The Failure', p. 512; Dumett, El Dorado.

${ }^{96}$ Ibid., p. 153.

${ }^{97}$ Ibid., p. 222.

${ }^{98}$ Chauveau et al., Changes in Land Access.

${ }^{99}$ cf. Raymond E. Dumett, 'Parallel Mining Frontiers in the Gold Coast and Asante in the late $19^{\text {th }}$ and Early $20^{\text {th }}$ Centuries', in Mining Frontiers in Africa. Anthropological and Historical Perspectives, eds. Katija Werthmann and Tilo Grätz (Köln, 2012), pp. 33-54, esp. p. 40; and Ade Renner-Thomas, Land Tenure in Sierra Leone. The Law, Dualism and the Making of a Land Policy (Central Milton Keynes, 2010).

${ }^{100}$ In Sierra Leone, Paramount Chiefs are, by definition, the custodians of the land (Renner-Thomas, Land Tenure). 
${ }^{101}$ Ibid., p. 172.

${ }^{102}$ Chauveau and Richards, 'West African Insurgencies'.

${ }^{103}$ Igor Kopytoff, The African Frontier. The Reproduction of Traditional African Societies (Bloomington, 1987).

${ }^{104}$ For the Sierra Leone's case, see Fenda A. Akiwumi, 'Strangers and Sierra Leone Mining: Cultural Heritage and Sustainable Development Challenges', Journal of Cleaner Production, 84, 1 (2014), 773-782; V. R Dorjahn and Christopher Fyfe, 'Landlord and Stranger: Change in Tenancy Relations in Sierra Leone', Journal of African History, 3, 3 (1962), 391-397; Bruce L. Mouser, 'Landlords-Strangers: A Process of Accomodation and Assimilation', International Journal of African Historical Studies, 8, 3 (1975), 425-440. For a more broader historical and geographical perspective on this region, see George E. Brooks, Landlords and Strangers: Ecology, Society and Trade in Western Africa, 1000-1630 (Boulder, 1993).

105 Matthieu Bolay, 'When Miners Become "Foreigners": Competing Categorizations Within Gold Mining Spaces in Guinea', Resource Policy, 40 (2014), 117-127, see p. 120. Sabine Luning shows the complexity of the interaction among multiple actors (from international mining companies to "earth priests") in present Burkina Faso's gold mines (Sabine Luning, 'Beyond the Pale of Property: Gold Miners Meddling with Mountains in Burkina Faso", in Worlds of Debts. Interdisciplinary Perspectives on Gold Mining in West Africa, ed. Panella (Amsterdam, 2010), pp. 25-48. See also Sabine Luning, 'Processing Promises of Gold: A Minefield of Company-community Relations in Burkina Faso', Africa Today, 58, 3 (2012), 23-39.

${ }^{106}$ Chauveau and Richards, 'West African Insurgencies', p. 525.

${ }^{107}$ Ibid., p. 525.

${ }^{108}$ Chauveau et al., Changes in Land Access, pp. 11, 15; Chauveau and Richards, 'West African Insurgencies', p. 525.

${ }^{109}$ Chauveau and Richards, 'West African Insurgencies', p. 527.

${ }^{110}$ See, for example, Bolay, 'When Miners Become "Foreigners".

${ }^{111}$ See, for example, Jan Jensen, 'What Gold Mining Means for the Malinke, and How it was Misunderstood by the French Colonial Administration', in Worlds of Debts. Interdisciplinary Perspectives on Gold Mining in West Africa, ed. Cristiana Panella (Amsterdam, 2010), pp. 95-110, esp. p. 97.

${ }^{112}$ See, for example, Katija Werthmann, 'Gold Mining in Burkina Faso since the 1980s', in Mining Frontiers in Africa. Anthropological and Historical Perspectives, eds. Katija Werthmann and Tilo Grätz (Köln, 2012), pp. $119-132$. 
113 See, for example, Tilo Grätz, 'Gold Mining in the Atakora Mountains (Benin): Exchange Relations in a Volatile Economic Field', in Mining Frontiers in Africa. Anthropological and Historical Perspectives, eds. Katija Werthmann and Tilo Grätz (Köln, 2012), pp. 97-118.

114 cf. Chauveau and Richards, 'West African Insurgencies', p. 545.

${ }^{115}$ Chauveau and Richards, 'West African Insurgencies', p. 539; see also p. 537.

${ }^{116}$ cf. Robertson, 'Abusa'.

${ }^{117}$ Michael Jackson, Life Within Limits. Well-Being in a World of Want (Durham-London, 2011), p. 158.

118 Ibid.

${ }^{119}$ Cf. Morfino, Il Tempo della Moltitudine, pp. 29, 125.

${ }^{120}$ Wittgenstein, Philosophical Investigations.

${ }^{121}$ Frederick Cooper, 'African Labor History', in Global Labour History. A State of Art, ed. Jan Lucassen (Bern 2006), pp. 91-116, esp. p. 93. 